\title{
A study on value added dairy products and availability of milk, meat and egg at consumers' level in selected areas of Bangladesh
}

\author{
M.T. Uddin ${ }^{1}$, M.M. Islam² and M. Nasrin ${ }^{1}$ \\ ${ }^{1}$ Department of Agricultural Economics, Bangladesh Agricultural University, Mymensingh- 2202, \\ ${ }^{2}$ Farming System Research Division, Bangladesh Livestock Research Institute, Savar, Dhaka-1341
}

\begin{abstract}
The goal of the study was to analyze the different actors involved in the dairy products value chain with their value addition activities and estimate the demand for livestock products through measuring the availability of milk, meat and egg at individual level. With this goal, the study was conducted in four districts namely Sirajganj, Bogra, Rangpur and Narsingdi which were selected purposively for this study based on concentration of dairy farming and the presence of dairy processing plants/companies. The simple random sampling technique was followed to select a total of 240 from six types of stakeholders/ actors i.e., input suppliers, dairy farmers, milk traders, processing plants/companies including their branches/agents, credit organizations and service providers, and consumers of livestock products. Data and information were analyzed by using descriptive statistics, mathematical techniques, enterprise analysis, SWOT analysis and value chain analysis followed by graphical presentation. Cost of milk per litre was highest in Narsingdi (Tk. 25.33) and lowest in Sirajganj (Tk. 19.66). Dairy farmers in Narshingdi derived highest net return per cow per day (Tk. 109.48). Investment in dairy farming was highly profitable since BCR per day per cow in all the districts were more than one. Collection point/processing plants added highest value (35.5\%) to a product followed by farmers $(25.2 \%)$, milk traders $(28.3 \%)$ and retailers $(11.0 \%)$. The availability of milk, meat and egg was higher in all the study areas than the national average. The impact of price and income on quantity demand was statistically significant for all the products. The demand for milk and egg was price elastic whereas demand for meat was price inelastic. On the other hand, the demand for livestock products was found as income inelastic. However, in spite of various problems and threats, there is a great export potential for value added dairy products along with satisfying the unmet consumer demand in the domestic market for such products.
\end{abstract}

(Key words: Value addition, demand for livestock products, SWOT analysis and price elasticity)

\section{Introduction}

With the alarming growth of population in Bangladesh, demand for milk and dairy products is rising. As a result of the development of modern civilization and culture, particularly the emergence of high income, urban population have changed the pattern of dairy product consumption. They are becoming more enthusiastic toward processed milk and milk products over ordinary raw milk. Therefore, the uses of condensed milk, milk beverage, milk powder, butter, cheese, baby food, etc. have been considerably increased. In response to the growing needs of buyers and consumers, a large number of stakeholders including farmers, input suppliers, service providers, processing companies namely, Bangladesh Milk Producers' Cooperative Union Limited (Milk Vita), BRAC Dairy and Food Project (Arong), Pran Dairy Limited, Grameen Matso and Pashu Sampad Foundation (GMPF), Rangpur Dairy, etc. are producing different value added dairy products. Bangladesh has possibility to expand its dairy products' trade

*Corresponding author: tajbau@yahoo.com

Bang. J. Livs. Res. Special Vol. 21-25, 2018: P. 45-55, ISSN 1022-3851 
with other countries establishing value innovation and meeting safety standards properly.

The concept of value chain is defined as the entire range of activities required to bring a product from initiation, through various phases of production, to its final consumers. The production stages entail a combination of physical transformation and the participation of various producers and services and the chain includes the product's disposal after use (Kaplinsky and Morris, 2001). The value chain is relatively a new concept in the production and marketing literatures especially for dairy products.

However, acute shortage of livestock products such as milk, meat and egg has been prevailing in Bangladesh for a long time. Statistics shows that Bangladesh has a shortage of milk, meat and egg of 80, 84 and $63 \%$ of the total requirement of the country (BBS, 2010). The present study was designed to identify the existing actors involved in the chain with their specific functions. The study also analyzed the value addition at different levels of value chain of livestock products, effective demand by the consumers for livestock products especially milk, meat and egg, and the availability of those products at consumers' level. The specific objectives were as follows:

i) To identify the existing actors involved in the value chain of dairy products and analyze their activities;

ii) To estimate the value addition at different levels of value chain of dairy products;

iii) To measure the gap between the actual availability and projected demand for milk, meat and egg at consumers' level; and

iv) To suggest policy options for necessary improvement.

\section{Materials and Methods}

This research was performed jointly by the Bangladesh Agricultural University (BAU) and Bangladesh Livestock Research Institute (BLRI). Different villages of Belkuchi, Shahjadpur, Ullahpara and Sadar Upazila of Sirajgonj District; Gabtali, Nandigram, Sherpur and Sadar Upazila of Bogra District; Mithapukur, Pirganj and Sadar Upazila of Rangpur District; and Palash as well as Sadar Upazila of Narsingdi District were selected purposively for this study based on concentration of dairy farming and the presence of dairy processing plants/ companies. Simple random sampling and face-to-face interview method were used for a total sample of 240 , covering 06 types of stakeholders/actors taking 40 input suppliers, 40 dairy farmers, 40 milk traders, 40 processing plants/companies (including their branches/agents/collection points), 40 credit organizations and service providers; and 40 consumers of livestock products. Primary data were collected from field surveys, focus group discussions (FGD) and key informant interview (KII). Data and information were analyzed by using descriptive statistics (i.e., sum, average, percentages, ratios, standard deviations, standard errors, etc.), mathematical techniques, enterprise analysis, SWOT analysis and value chain analysis followed by graphical presentation. To estimate the value addition at different levels of milk value chain, the following equations were used: 
i) Profitability analysis:

$\Pi=\sum_{i=1}^{n}\left(P_{Y_{i}} \cdot Y_{i}\right)-\sum_{i=1}^{n}\left(P_{X_{i}} \cdot X_{i}\right)-T F C$

(Awal et al., 2007)

Where, $\Pi=$ Profit (Tk./unit);

$\mathrm{P}_{\mathrm{X}_{\mathrm{i}}=\text { Price per unit of the } \mathrm{i} \text {-th produce }}$

(Tk./litre); $\mathrm{Y}_{\mathrm{i}}=$ Quantity of the $\mathrm{i}$-th produce (litre/day/cow); $\mathrm{P}_{\mathrm{Y}_{\mathrm{i}}}=$ Price per unit of the $\mathrm{i}$-th inputs (Tk./unit); $\quad \mathrm{X}_{\mathrm{i}}=$ Quantity of the $\mathrm{i}$-th inputs $(\mathrm{Kg} /$ day/cow $) ; \mathrm{TFC}=$ Total fixed costs (Tk.); and $\mathrm{i}=1,2,3, \ldots, \mathrm{n}$ (number of items).

ii) Value addition by milk producers $=($ Sales price - Production cost $)$

iii) Value addition by individual actor $=($ Sales price - Purchase price $)$

Moreover, to estimate actual availability of milk, meat and egg at consumers' level, a simple linear regression model of the following form was estimated:

$\mathrm{Y}=\mathrm{b}_{0}-\mathrm{b}_{1} \mathrm{X}_{1}+\mathrm{b}_{2} \mathrm{X}_{2}$

(Gujarati, 2003)

Where, $\mathrm{Y}=$ Availability of milk, meat and egg at consumers' level; $\mathrm{X}_{1}=$ Price of the product; $\mathrm{X}_{2}=$ Income of the consumer; and $b_{1}$ and $b_{2}=$ Production coefficients of the respective variables. The t-statistic was applied to test the significance of relevant parameters. Price elasticity and income elasticity were also estimated using the following formulae to estimate the responsiveness of consumer demand to a change in products' price or consumers' income: Price elasticity, $\mathrm{Ep}=\Delta \mathrm{Q} / \Delta \mathrm{P}$. $\mathrm{P} / \mathrm{Q}$ Income elasticity, $\mathrm{Ei}=\Delta \mathrm{Q} / \Delta \mathrm{I}$. I/Q (Ahuja, 1980)

Where, $\Delta \mathrm{Q}=$ Change in quantity demand; $\Delta \mathrm{P}=$ Change in price; $\Delta \mathrm{I}=$ Change in income; $\mathrm{Q}=$ Quantity demand; $\mathrm{P}=$ Market price of the product; and I = Income of consumer.

\section{Results and Discussion}

\section{Actors involved in the dairy products' value chain and their activities}

The major actors involved in the dairy value chain with their activities are discussed below:

\section{Dairy farmers}

Dairy farmers in the study area mainly produce dairy products independently and sell them to various middlemen like milk traders, retailers, different processing plants and directly consumers as well from their farm gate. They perform some sort of processing activities also such as preserving, cooling, etc. Farmers in the study areas mainly process ghee and curd from milk.

\section{Milk traders}

Traders are those persons who collect milk from individual farmers and various dairy farms. They sell the product to buyers at local markets, house to house, hotels, shops, retailers, different collection points or processing plants. Traders adding value with the milk through preserving and cooling.

\section{Collection point/Processing plants}

The most important collection point/ processing plants were BRAC, Milk Vita, PRAN, Rangpur Dairy, etc. They collected milk from farmers, dairy farm and traders; and perform various kinds of processing functions such as storing, preserving, chilling, pasteurizing, etc. They make powder milk, pasteurized milk, ghee, chhana, curd, butter, ice-cream, chocolate, etc. from fresh milk through different processes as well as add value according to the forms of the products. 


\section{Retailers}

The retailers purchase processed milk and milk products from traders or processing plants and non-processed milk from producers; and sell them to direct consumers. Various shops, restaurants, tea stalls, hotels, sweetmeat shops also perform the functions of retailing.

\section{Consumers}

Consumers are the ultimate user of value added dairy products. They mainly purchase dairy products from retailers and also from traders or producers.

\section{Input supplier}

Input suppliers are the basic support service providers in the dairy value chain. Various types of feeds, medicines, veterinary services are needed for dairy rearing. These are supplied by different traders, millers, dealers, wholesalers, veterinarian, pharmacist who collect those inputs from various companies, feed mills, raw material suppliers

Table 1. Services rendered by different stakeholders (Percentage of responses)

\begin{tabular}{|c|c|c|c|c|c|}
\hline Services & Sirajganj & Bogra & Rangpur & Narsingdi & Average \\
\hline \multicolumn{6}{|c|}{ Input suppliers } \\
\hline Treatment and vaccination & 10 & 20 & 20 & 30 & 20 \\
\hline Storing and cleaning & 100 & 20 & 20 & 60 & 50 \\
\hline Processing and packaging & 10 & 20 & 20 & 30 & 20 \\
\hline Quality control & 10 & 10 & 10 & 10 & 10 \\
\hline Artificial insemination & 10 & 10 & 10 & 10 & 10 \\
\hline Selling & 100 & 100 & 100 & 100 & 100 \\
\hline \multicolumn{6}{|c|}{ Dairy farmers } \\
\hline Milking & 100 & 100 & 100 & 100 & 100 \\
\hline Cleaning & 100 & 100 & 100 & 100 & 100 \\
\hline Preserving & 10 & - & 10 & 10 & 10 \\
\hline Value adding & 50 & 60 & 40 & 30 & 60 \\
\hline Selling & 100 & 100 & 100 & 100 & 100 \\
\hline \multicolumn{6}{|c|}{ Milk traders } \\
\hline Collection & 100 & 100 & 100 & 100 & 100 \\
\hline Preserving & 100 & 100 & 100 & 100 & 100 \\
\hline Cooling & 100 & 100 & 100 & 100 & 100 \\
\hline Quality control & 80 & 70 & 60 & 50 & 65 \\
\hline Value adding & 100 & 100 & 100 & 100 & 100 \\
\hline \multicolumn{6}{|c|}{ Collection point/Processing plants } \\
\hline Collection & 100 & 100 & 100 & 100 & 100 \\
\hline Preserving & 100 & 100 & 100 & 100 & 100 \\
\hline Chilling & 100 & 100 & 100 & 100 & 100 \\
\hline Pasteurization & 100 & 100 & 100 & 100 & 100 \\
\hline Value adding & 100 & 100 & 100 & 100 & 100 \\
\hline Quality control & 100 & 100 & 100 & 100 & 100 \\
\hline
\end{tabular}

Source: Authors' estimation based on field survey, 2013. 
or from local markets. The services rendered by input suppliers are storing, cleaning, processing, packaging, etc. Sometimes, dairy farmers purchase green grass, straw, etc. from neighbors and local markets.

\section{Credit organizations}

Credit organizations also play a good role in the dairy value chain. They (namely, BRAC, ASA, TMSS, RAKAB, SSS and NSKF) provide credit for dairy farming or dairy related activities. They also provided some other services such as training to farmers, technical services, information related to product selling, etc.

The dairy products' value chain describes the way in which the dairy products flow from its inception to ultimate users. The activities of various actors involved in dairy products' value chain were identified as percentage in Table 1 which is also presented by flow chart 1 . The table reveals that all the stakeholders were rendering almost full extent of their services to make the value added dairy products.

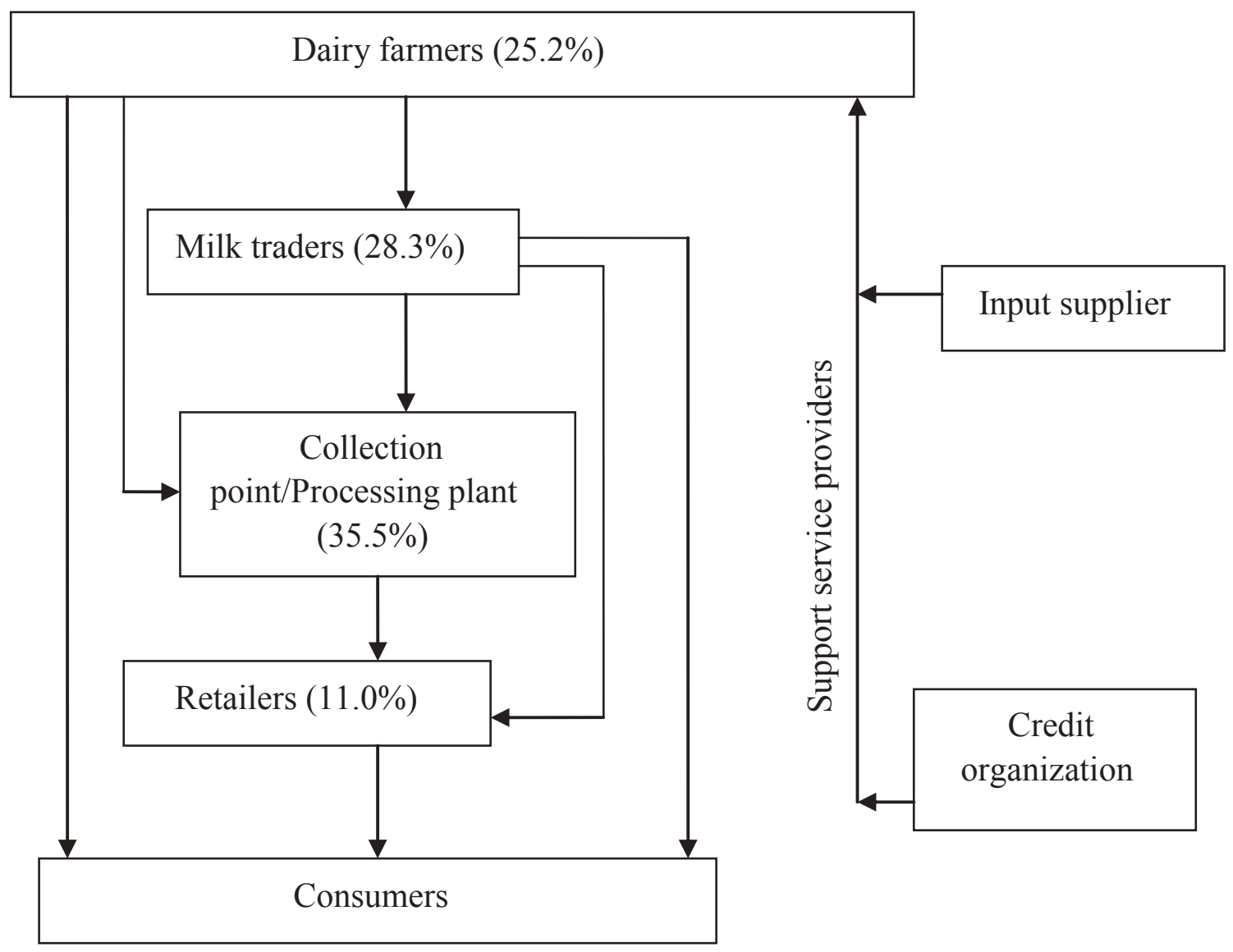

Flowchart 1: Dairy products' value chain

Note: Figures within the parentheses indicate percentage of the total value addition. 
Value addition at different levels of dairy products' value chain

\section{Production cost and return of milk of dairy farmers}

Total cost of rearing of a milch cow per day was estimated at Tk. 84.10 in Narsingdi followed by Rangpur (Tk. 71.99), Sirajganj (Tk. 68.80) and Bogra (Tk. 62.20) (Table 2). Cost of milk per litre was highest in Narsingdi (Tk. 25.33) and lowest in Sirajganj (Tk. 19.66) (Table 4).
Sirajganj, Bogra, Rangpur and Narshingdi, respectively (Table 4). Dairy farming is more profitable in Narshingdi compared to other districts.

In all the areas, total variable cost comprises about 95 percent of total cost (Table 2). The return item consisted of return from milk, net change in inventory and value of cowdung. Table 3 reveals that dairy farmers in Narshingdi derived higher average gross

Table 2. Rearing cost of milch cow (Tk./cow/day)

\begin{tabular}{lcccccc}
\hline Cost items & Sirajganj & Bogra & Rangpur & Narsingdi & Average \\
\hline Feed & 40.83 & 37.45 & 45.6 & 50.87 & 43.69 \\
& $(59.35)$ & $(60.20)$ & $(63.34)$ & $(60.49)$ & $(60.87)$ \\
Labour & 22.6 & 19.61 & 20.24 & 27.52 & 22.49 \\
& $(32.85)$ & $(31.53)$ & $(28.11)$ & $(32.72)$ & $(31.33)$ \\
Veterinary service & 0.93 & 0.54 & 0.47 & 1.20 & 0.79 \\
& $(1.35)$ & $(0.87)$ & $(0.65)$ & $(1.43)$ & $(1.10)$ \\
Water and electricity & 1.10 & 0.98 & 1.05 & 0.87 & 1.00 \\
& $(1.60)$ & $(1.58)$ & $(1.46)$ & $(1.03)$ & $(1.39)$ \\
Miscellaneous & 0.20 & 0.35 & 0.17 & 0.45 & 0.29 \\
& $(0.29)$ & $(0.56)$ & $(0.24)$ & $(0.53)$ & $(0.40)$ \\
\hline Total variable cost & 65.66 & 58.93 & 67.53 & 80.91 & 68.26 \\
& $(95.44)$ & $(94.74)$ & $(93.80)$ & $(96.21)$ & $(95.14)$ \\
\hline Interest on operating & 2.71 & 2.91 & 4.05 & 2.90 & 3.14 \\
capital & $(3.94)$ & $(4.68)$ & $(5.63)$ & $(3.45)$ & $(4.37)$ \\
Housing cost & 0.47 & 0.36 & 0.41 & 0.29 & 0.38 \\
& $(0.68)$ & $(0.58)$ & $(0.57)$ & $(0.34)$ & $(0.53)$ \\
\hline Total fixed cost & 3.18 & 3.27 & 4.46 & 3.19 & 3.52 \\
& $(4.62)$ & $(5.26)$ & $(6.20)$ & $(3.79)$ & $(4.90)$ \\
\hline Total cost & 68.80 & 62.20 & 71.99 & 84.10 & 71.78 \\
& $(100.00)$ & $(100.00)$ & $(100.00)$ & $(100.00)$ & $(100.00)$ \\
\hline
\end{tabular}

Source: Field survey, 2013; Figures within the parentheses indicate percentage.

The investment in the selected dairy farming was highly profitable since BCR per day per cow in all the districts were more than one. Thus, investment of Tk. 1 gave return of Tk. 2.10, Tk. 1.80, Tk. 1.50 and Tk. 2.30 in return per cow per day (Tk. 193.58). The highest net return was also estimated in Narshingdi (Tk. 109.48). 
Table 3. Return from dairy farming (Tk./cow/day)

\begin{tabular}{lc|c|c|c|c}
\hline Particulars & Sirajganj & Bogra & Rangpur & Narsingdi & Average \\
\hline A) Return from milk production & & & & & \\
$\quad$ Lactation period (days) & 240 & 210 & 220 & 210 & 220 \\
$\quad$ Milk production (litre/day/cow) & 3.50 & 2.90 & 3.10 & 3.32 & 3.21 \\
$\quad$ Price per litre & 40.40 & 36.50 & 32.70 & 52.0 & 41.40 \\
$\quad$ Total & 141.40 & 105.85 & 101.37 & 185.92 & 133.64 \\
B) Net change in inventory & 5.25 & 5.90 & 4.83 & 6.10 & 5.52 \\
C) Return from cowdung & 1.20 & 1.98 & 2.10 & 1.56 & 1.71 \\
D) Gross return (A+B+C) & 147.85 & 113.73 & 108.30 & 193.58 & 140.87 \\
\hline
\end{tabular}

Source: Authors' estimation based on field survey, 2013.

Table 4. Profitability of dairy rearing (Tk./cow/day)

\begin{tabular}{lcccccc}
\hline Particulars & Sirajganj & Bogra & Rangpur & Narsingdi & Average \\
\hline A) Gross return & 147.85 & 113.73 & 108.30 & 193.58 & 140.87 \\
B) Gross cost & 68.80 & 62.20 & 71.99 & 84.10 & 71.77 \\
C) Net return & 79.05 & 51.53 & 36.31 & 109.48 & 69.09 \\
D) Cost of milk per litre (Tk.) & 19.66 & 21.45 & 23.22 & 25.33 & 22.42 \\
E) Net return per litre of milk (Tk.) & 22.59 & 17.77 & 9.48 & 32.98 & 20.71 \\
E) BCR (Undiscounted) & 2.10 & 1.80 & 1.50 & 2.30 & 1.93 \\
\hline
\end{tabular}

Source: Authors' estimation based on field survey, 2013.

Value addition by different actors involved in the dairy value chain

Dairy farmers provided some sort of services for which they have to incur marketing cost. The value addition by dairy farmers was the highest in Narshingdi (Tk. 26.7) followed by Sirajganj (Tk. 20.7), Bogra (Tk. 15.0) and
Rangpur (Tk. 9.5). Milk traders usually sold raw and processed milk to retailers or collection point/ processing plants. They were performed various kinds of marketing functions. Milk traders in Bogra added Tk. 12.1 to its purchase price whereas, traders in Rangpur added Tk. 5.9 to the purchase price (Table 5).

Table 5. Value addition by dairy farmers and milk traders of dairy value chain (Tk./litre)

\begin{tabular}{lcccccc}
\hline Particulars & Sirajganj & Bogra & Rangpur & Narsingdi & Average \\
\hline Farmers' sale price & 40.4 & 36.5 & 32.7 & 52.0 & 41.4 \\
Farmers' production cost & 19.7 & 21.5 & 23.2 & 25.3 & 22.4 \\
Farmer's marketing cost & 3.2 & 1.2 & 1.3 & 2.6 & 2.0 \\
Farmers' profit & 17.5 & 13.8 & 8.2 & 24.1 & 15.9 \\
Value addition by farmers & 20.7 & 15.0 & 9.5 & 26.7 & 17.9 \\
\hline Purchase price of milk traders & 40.4 & 36.5 & 32.7 & 52.0 & 41.4 \\
Marketing cost of milk traders & 2.3 & 3.9 & 4.6 & 3.4 & 3.6 \\
Traders' sales price & 52.4 & 52.5 & 45.2 & 65.5 & 53.9 \\
Traders' profit & 9.7 & 12.1 & 5.9 & 6.1 & 8.5 \\
Value addition by milk traders & 12.0 & 16.0 & 10.5 & 9.5 & 12.0 \\
\hline
\end{tabular}

Source: Authors' estimation based on field survey, 2013. 
On an average, farmers added about $25.2 \%$ value to their dairy products. Value addition by milk traders was $28.3 \%$. Collection points/ processing plants added about $35.5 \%$ value of a value added dairy product whereas retailers added about $11.0 \%$ value to their products (Table 6).

Table 6 . Value addition by different stakeholders/ actors for major value added dairy products (In percentage)

\begin{tabular}{l|c}
\hline Particulars & Average \\
\hline Value addition by farmers & 25.2 \\
Value addition by milk traders & 28.3 \\
Value addition by collection & \\
point/processing plants & 35.5 \\
Value addition by retailers & 11.0 \\
\hline
\end{tabular}

Source: Authors'estimation based on field survey, 2013.
Thus, collection point/ processing plants added highest value to a product. The major value added products found in this study are pasteurized milk, powder milk, butter, ghee, curd, ice-cream and milk chocolate.

\section{Availability and demand of milk, meat and egg at consumers' level}

Although milk, meat and egg are important contributors to human protein needs, the consumption of dairy products in Bangladesh is very low even when compared to neighboring countries. The average daily consumption of milk is $45 \mathrm{ml}$ per day/person against a recommended amount of $250 \mathrm{ml} /$ day (Begum et al., 2010). The daily requirement, availability and gap between these two in the study areas are shown in Table 7. The actual purchases made by the individuals were considered as the

Table 7. Per capita availability and requirements for dairy products at consumers' level

\begin{tabular}{|c|c|c|c|}
\hline Products & Daily requirement & Availability & Deficit \\
\hline \multicolumn{4}{|c|}{ Sirajganj } \\
\hline Milk (ml/day) & 250 & 80.2 & 169.8 \\
\hline Meat (gm/day) & 120 & 35.8 & 84.2 \\
\hline Egg (number/year) & 104 & 62.3 & 41.7 \\
\hline \multicolumn{4}{|c|}{ Bogra } \\
\hline Milk (ml/day) & 250 & 68.9 & 181.1 \\
\hline Meat (gm/day) & 120 & 29.1 & 90.9 \\
\hline Egg (number/year) & 104 & 43.4 & 60.6 \\
\hline \multicolumn{4}{|c|}{ Rangpur } \\
\hline Milk (ml/day) & 250 & 76.4 & 173.6 \\
\hline Meat (gm/day) & 120 & 25.6 & 94.4 \\
\hline Egg (number/year) & 104 & 51.2 & 52.8 \\
\hline \multicolumn{4}{|c|}{ Narsingdi } \\
\hline Milk (ml/day) & 250 & 59.8 & 190.2 \\
\hline Meat (gm/day) & 120 & 26.8 & 93.2 \\
\hline Egg (number/year) & 104 & 38.5 & 65.5 \\
\hline \multicolumn{4}{|c|}{ Average } \\
\hline Milk (ml/day) & 250 & 71.3 & 178.7 \\
\hline Meat (gm/day) & 120 & 29.3 & 90.7 \\
\hline Egg (number/year) & 104 & 48.9 & 55.2 \\
\hline
\end{tabular}

Source: Field survey, 2013. 
availability of dairy products. The gap between availability and requirement is very pronounced because majority of people do not have adequate buying ability.

The availability of a particular dairy product at consumer level is mainly influenced by its own price, average per capita income and other demographic variables. The average impact of consumer's income and market prices of products is estimated with the help of a simple linear regression model. Results of linear regression model for meat, milk and egg have been shown below:

$$
\begin{aligned}
& \mathrm{Y}=32.65-2.31 \mathrm{X}_{1}{ }^{*}+3.87 \mathrm{X}_{2}{ }^{* *} \text { : For milk } \\
& \text { S.E. }(0.29) \quad(0.78) \quad R^{2}=0.48 \\
& \mathrm{Y}=19.60-0.97 \mathrm{X}_{1}{ }^{* *}+1.36 \mathrm{X}_{2}{ }^{* *} \text { : For meat } \\
& \text { S.E. (0.30) (0.52) } \quad \mathrm{R}^{2}=0.31 \\
& \mathrm{Y}=42.83-1.25 \mathrm{X}_{1}{ }^{* *}+2.54 \mathrm{X}_{2}{ }^{* *} \text { : For egg } \\
& \text { S.E. (0.32) (0.43) } \quad \mathrm{R}^{2}=0.63
\end{aligned}
$$

Where,

$\mathrm{Y}=$ Actual availability at consumers' level;

$\mathrm{X}_{1}=$ Price of the product; and

$\mathrm{X}_{2}=$ Income of the consumer.

Note: ** Significant at 5 percent probability level; * Significant at 10 percent probability level.

Market price has a negative impact and income of consumer has a positive impact on availability of dairy products. The price coefficient was found at $-2.31,-0.97$ and -1.25 for milk, meat and egg which means that if price increases by 1 unit, the availability of milk, meat and egg was reduced by 2.31, 0.97 and 1.25 unit, respectively, other things remaining the same. On the other hand, if income increased by one unit, consumption of milk, meat and egg was increased by 3.87, 1.36 and 2.54 units, respectively, other things held constant. The impact of price and income on quantity demand was statistically significant for all the products. But the value of R2 was lower for meat which implies that there were factors other than price and income which affect quantity demand of consumers.
The price and income elasticity were also estimated to measure the responsiveness of consumers to change in price and income of livestock products which is presented in Table 8 .

Table 8. Price and income elasticity of demand for livestock products

\begin{tabular}{lcc|c}
\hline Items & Milk & Meat & Egg \\
\hline Price elasticity & -1.02 & -0.92 & -1.3 \\
Income elasticity & 0.68 & 0.55 & 0.71 \\
\hline
\end{tabular}

Source: Authors' estimation, 2013.

Estimated price elasticity of demand for milk, meat and egg was -1.02, -0.92 and -1.3 , respectively which meant that quantity demand was decreased by $1.02 \%, 0.92 \%$ and $1.30 \%$; on an average, due to $1 \%$ increase in price of these products, other things remaining the same and vice versa. Moreover, the demand for meat was price inelastic. On the other hand, demand for livestock products were increased by $0.68 \%$, $0.55 \%$ and $0.71 \%$; on an average, due to $1 \%$ increased in income, keeping all other things remaining constant. Therefore, the demand for livestock products was found as income inelastic.

\section{SWOT analysis on value added dairy products}

SWOT (Strength, Weakness, Opportunity and Threat) analysis was done to identify the problems and potentials of value added dairy products (Kotler et al., 2009). Majority of the respondents $(92 \%)$ reported that dairy enterprise is a source of income and employment (Table 9). About 58\% respondents think that fluctuation in milk production and price is a major weakness of this sector. Marketing of foreign dairy products in domestic market, lack of grazing land, lack of quality control measure are the major threats towards developing dairy sector in the country. In spite of all these problems and threats, there is a clear cut and tremendous opportunities for the improvement of dairying. 
Table 9. SWOT analysis on value added dairy products

\begin{tabular}{|c|c|c|c|}
\hline Strengths & $\begin{array}{c}\% \text { of } \\
\text { responses }\end{array}$ & Weaknesses & $\begin{array}{c}\% \text { of } \\
\text { responses }\end{array}$ \\
\hline $\begin{array}{l}\text { - Source of income and employment } \\
\text { - Increasing number of dairy } \\
\text { processing plants } \\
\text { - Increased availability of milk for } \\
\text { processing }\end{array}$ & $\begin{array}{l}71 \\
65\end{array}$ & $\begin{array}{ll}\text { - } & \text { Low productivity } \\
\text { - } & \text { Fluctuations in milk } \\
& \text { production and price } \\
\text { - } & \text { Lack of credit facilities } \\
\text { - } & \text { Poor logistic supports }\end{array}$ & $\begin{array}{l}58 \\
37 \\
32\end{array}$ \\
\hline Opportunities & & Threats & \\
\hline $\begin{array}{l}\text { - Great export potential for value } \\
\text { added dairy products } \\
\text { - Unmet demand for value added } \\
\text { dairy products in domestic market } \\
\text { Potential for larger capacity } \\
\text { utilization of milk collection } \\
\text { points/processing plant s }\end{array}$ & $\begin{array}{l}90 \\
87\end{array}$ & $\begin{array}{l}\text { - Marketing of foreign dairy } \\
\text { products in domestic } \\
\text { market } \\
\text { - Lack of grazing land } \\
\text { - Lack of quality control } \\
\text { measure }\end{array}$ & 57 \\
\hline
\end{tabular}

Source: Field survey, 2013.

\section{Conclusion}

The study analyzed the different actors involved in the chain of value added dairy products with their value addition activities and estimated the demand for livestock products through measuring the availability of milk, meat and egg at individual level. The activities of various actors involved in milk value chain were identified and the chain of value added dairy products was identified. It was revealed that collection point/ processing plants added highest value to a product. However, as compared to national statistics, the gap between availability and requirement was very pronounced in the study areas because majority of people do not have adequate buying ability. Availability of milk, meat and egg was higher in all the study areas than the national average. A significant impact of product price and consumer income was found on the demand for milk, meat and egg in all the districts. Marketing of foreign dairy products in domestic market, lack of grazing land, lack of quality control measure are the major threats towards developing dairy enterprise in the country. In spite of all these threats, there is a clear cut and tremendous opportunities for the improvement of dairying. It may be concluded that there is a great export potential for value added dairy products; and satisfy the unmet consumer demand in the domestic market with such products which will lead in increase the overall income from livestock sub-sector. Therefore, formulation of long-term plan is essential to increase the production of livestock and livestock products to fulfill the ever-increasing demand of the country.

\section{References}

Ahuja, H.L. 1980. Modern Economics (Revised Edition), S. Chand \& Company Ltd., New Delhi.

Awal, M.A., Saha, S.R., Khaled, M.M. and Khan, M.A. 2007. An economic analysis of sweet potato cultivation in some selected char areas of Bangladesh. Journal of Bangladesh University, 5(1): 159-167

BBS. 2010. Statistical Yearbook of Bangladesh, Bangladesh Bureau of Statistics, Statistics Division, Ministry of Planning, Government of the People's Republic of Bangladesh, Dhaka. 
Begum, J., Raha, S.K., Uddin, M.T. and Fatema, J. 2010. A study on milk marketing in selected areas of Bangladesh. Proceedings of the Annual Research Review Workshop, Bangladesh Livestock Research Institute, Savar, Dhaka, pp. $330-348$

BER. 2011. Bangladesh Economic Review, Economic Advisory Section, Department of Finance, Ministry of Finance, Bangladesh.
Kaplinsky, R. and Morris, M. 2001. A handbook for value chain research. University of Sussex, UK.

Gujarati, D.N. 2003. Basic Econometric, Fourth Edition, Mcgraw-Hill Inc., New York.

Kotler, P. Keller, K.L., Koshy, A. and Jha, M. 2009. Marketing Management (Thirteen edition). Pearson Prentic Hall TM, New York. 